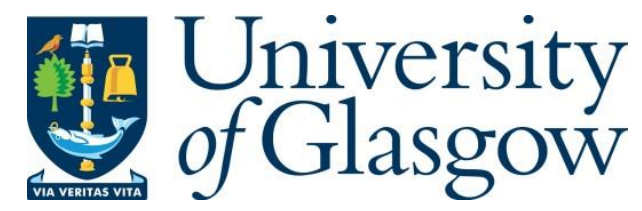

Judge, A. and Maltby, T. (2017) European Energy Union? Caught between securitisation and 'riskification'. European Journal of International

Security, 2(2), pp. 179-202. (doi:10.1017/eis.2017.3)

This is the author's final accepted version.

There may be differences between this version and the published version. You are advised to consult the publisher's version if you wish to cite from it.

http://eprints.gla.ac.uk/133004/

Deposited on: 19 December 2016

Enlighten - Research publications by members of the University of Glasgow http://eprints.gla.ac.uk 


\section{European Energy Union? Caught between Securitisation}

\section{and 'Riskification'}

Abstract: Fears about the security of supplies have been central to debates about the development of an integrated EU energy policy over the past decade, leading to claims that energy has been 'securitised'. Previous analyses have found, however, that although shared security concerns are frequently used as a justification for further integration, then can also serve as a rationale for Member States to resist sharing sovereignty. Transcending this apparent paradox would require not just agreement about whether energy supplies are security concerns, but also agreement about what kind of security concern they are. In this article, we examine whether such an agreement could emerge through a comparative analysis of constructions of gas security in the UK and Poland. Utilising a framework that draws from both the philosophical and sociological wings of Securitisation Studies, we demonstrate that although gas has been elevated on the security agendas of both states, the specific logic of insecurity - securitisation or riskification underpinning these constructions differs substantially, and is conditioned by distinct modes of governance in each Member State. This, we contend, limits the potential for further integration of EU energy policies in the context of the European Commission's proposals for an 'Energy Union'. 


\section{Keywords}

energy security; securitisation; EU energy; energy governance

\section{Introduction}

For over a decade, the European Commission ${ }^{1}$ has regularly warned that the security of EU energy supplies, particularly gas, is at risk. The intensity and resonance of these concerns has steadily increased, following temporary disruptions to gas imports, the enlargement of the EU to include Member States highly dependent on external supplies, and the deterioration of political relations between the EU and its main supplier Russia. Such warnings have frequently acted as impetuses for the Commission to propose further integration of national energy policies, often as a means of sharing risks and increasing the security of supplies. This has generated a vibrant debate about the prospects for the further integration of EU energy policy, in the face of continuing and developing threats to energy security. ${ }^{2}$

While many observers have characterised these developments as the 'securitisation' of EU energy policy, ${ }^{3}$ there have been relatively few

\footnotetext{
${ }^{1}$ Hereafter referred to as the Commission.

2 For example, Vicki L. Birchfield, and John S. Duffield (eds.) Toward a Common European Union Energy Policy: Problems, Progress and Prospects (Basingstoke: Palgrave Macmillan, 2011); Kacper Szulecki, Severin Fischer, Anne T. Gullberg, and Oliver Sartor, 'Shaping the 'Energy Union': between national positions and governance innovation in EU energy and climate policy', Climate Policy 16:5 (2016), pp. 548-567.

${ }^{3}$ Sandra Lavenex, 'EU external governance in 'wider Europe', Journal of European Public Policy 11:4 (2004), pp. 692-3; Jelena Radoman, 'Securitization of Energy as a Prelude to Energy Security Dilemma', Western Balkans Security Observer 4 (2007), pp. 36-44;
} 
attempts to specifically examine these developments through the lens of securitisation theory. ${ }^{4}$ The few attempts to do so have reached different conclusions about whether securitisation has been successful or not, ${ }^{5}$ and in doing so have highlighted an apparent paradox at the heart of EU energy policy. While shared security concerns are frequently used as a justification for further integration, ${ }^{6}$ they can also serve as a rationale for Member States to resist any transfer or sharing of competences. ${ }^{7}$ As a result, the relationship between securitisation and integration remains ambiguous and poorly understood.

We argue that the key to understanding this relationship is to examine securitisation not just in terms of whether there is intersubjective agreement about whether energy is a security concern, but also whether there is

Richard Youngs, Energy Security: Europe's New Foreign Policy Challenge (London: Routledge 2009), p. 41; Eamonn Butler, 'The Geopolitics of Merger and Acquisition in the Central European Energy Market', Geopolitics 16:3 (2011), pp. 626-654.

${ }^{4}$ A core claim of securitisation theory, which we follow in this article, is that 'security' has no fixed or objective meaning. Instead it is socially constructed.

${ }^{5}$ Michal Natorski and Anna Herranz-Surrallés, 'Securitizing Moves to Nowhere? The Framing of the European Union Energy Policy', Journal of Contemporary Research 4:2 (2008), pp. 71-89; Francis McGowan, 'Putting Energy Insecurity into Historical Context: European Responses to the Energy Crises of the 1970s and 2000s', Geopolitics 16:3 (2011a), pp. 486-511.

${ }^{6}$ Emil Kirchner and Can Berk anticipate greater cooperation, integration and a common EU energy policy, driven by such energy security concerns. 'European Energy Security Cooperation: Between Amity and Enmity', Journal of Common Market Studies, 48:4 (2010), pp. 859-880.

${ }^{7}$ Pami Aalto and Dicle Korkmaz Temel are sceptical about the potential for substantial integration because of "a lack of shared beliefs and patterns of calculation". It is these beliefs that we interrogate. 'European Energy Security: Natural Gas and the Integration Process', Journal of Common Market Studies, 52:4 (2014): 758-774; 771. Tomas Maltby also highlights how security concerns are contested within member states, leading to inconsistent preferences on energy policy integration. 'Between Amity, Enmity and Europeanisation: EU Energy Security Policy and the Example of Bulgaria's Russian Energy Dependence', Europe-Asia Studies, 67:5 (2015), pp. 809-830. 
agreement about what kind of security concern they are. This requires taking a step back from the EU level and examining whether similar kinds of security concerns are present at the national level, which we do through a comparative analysis of attempts to securitise gas supplies in the UK and Poland. Rather than confining ourselves to a Copenhagen School understanding of securitisation, which adopts a narrow focus on the construction of discourses of existential threat, we adopt a wider approach that draws from both the philosophical and sociological wings of Securitisation Studies. From the philosophical wing, we utilise Corry's distinction between securitisation and riskification ${ }^{8}$ as a means of examining the different ways that gas has been constructed as a security issue in each Member State. From the sociological wing, we highlight the key role played by contextual features - namely established modes of market and state-led energy governance, and the role of gas in national energy systems - in enabling and constraining securitisation/riskification.

The central research problem we are addressing is why EU energy policy integration has been limited, despite claims by the Commission that a lack of integration poses a security threat. In our case studies we demonstrate that the UK and Polish governments have different conceptions of the insecurity of gas supplies within their respective countries: the former

\footnotetext{
${ }^{8}$ Olaf Corry, 'Securitisation and 'Riskification': Second-order Security and the Politics of Climate Change', Millennium: Journal of International Relations 40:2 (2012), pp. 235-258.
} 
conforming to a logic of riskification, and the latter conforming to a logic of securitisation. We argue that the presence of these different logics raises questions about whether the Commission can reconcile them into a common intersubjective understanding of threats as a means of legitimising the further integration of EU energy policy.

The article develops in four parts. The first outlines our theoretical framework, which focuses on multiple logics of insecurity and the role of contextual factors. Section two briefly traces the Commission's discourse of insecurity and its promotion of a predominantly liberal market approach to securing gas supplies in order to contextualise our comparative analysis. Sections three and four outline the empirical analysis of our case studies on the UK and Poland respectively. We conclude with reflections on the utility of the concepts of securitisation and riskification and the considerable barriers to premising further energy policy integration on security concerns.

\section{Securitising energy?}

The core argument of securitisation studies is that instead of examining whether or not real and objective threats exist, analysts should focus on the process through which such security issues are socially constructed. This enables an examination of how such issues emerge and dissolve, and what impact they have on politics and policymaking. The Copenhagen School's original securitisation framework focuses on an examination of political 
discourse for evidence of security speech acts, and their acceptance or rejection by a relevant audience. ${ }^{9}$ Within this framework, such speech acts take the form of an existential threat to the survival of a valued referent object. Successful securitisation is evident in the reproduction of these claims within wider political discourse and the development of a political environment in which extraordinary measures can be adopted which "break the normal political rules of the game". ${ }^{10}$

The Copenhagen School framework has been the subject of extensive critiques that have called into question almost every element of the theory. ${ }^{11}$ Many of these shortcomings become especially apparent when the theory is applied to different empirical cases, which highlight the often diverse ways in which (in)security is constructed in practice. This is especially the case when the framework has been used to examine energy politics in the EU, ${ }^{12}$ the USA, ${ }^{13}$ and East Asia, ${ }^{14}$ where the limitations of the Copenhagen School have been all too apparent. Two limitations are particularly relevant.

\footnotetext{
${ }^{9}$ Barry Buzan, Ole Wæver, and Jaap De Wilde, Security: A New Framework for Analysis (Boulder, CO: Lynne Rienner, 1998), p. 25.

${ }^{10}$ Ibid. p. 24.

11 For a recent summary see Thierry Balzacq, Sarah Léonard, and Jan Ruzicka, "Securitization' revisited: Theory and cases', International Relations [Early Online] (2015)

${ }^{12}$ Natorski and Herranz-Surrallés (2008); McGowan (2011a).

13 Jonna Nyman, 'Red Storm Ahead: Securitisation of energy in US-China relations', Millennium: Journal of International Studies 43:1 (2014), pp. 43-65.

${ }^{14}$ Andrew Phillips, 'A dangerous synergy: energy securitization, great power rivalry and strategic stability in the Asian century', The Pacific Review 26:1 (2013), pp. 17-38.
} 
The first is that the Copenhagen School focuses on a single essentialist logic of security based on existential threats to survival to the exclusion of other possible logics or meanings of insecurity. This is problematic because, as recent debates on the concept of energy security have highlighted, there are many possible 'meanings' of security based partly on the interests of different actors involved in energy trade and governance, and multiple dimensions or types of energy (in)security. ${ }^{15}$ To speak of energy security as if it were a single coherent discourse is highly questionable as such claims can take various forms across different contexts. ${ }^{16}$ Because of the plurality of possible security meanings, energy issues are a 'difficult case' to examine using the original Copenhagen School framework. Nonetheless, this does not mean that discourses of energy security have no effect on the form or content of energy policy. Instead it means that analysts should be attuned to the possibility that energy may be constructed as a security issue in different ways, in different contexts, and with different political consequences. ${ }^{17}$

\footnotetext{
${ }^{15}$ Bert Kruyt, Detlef P. van Vuuren, Han J. M. de Vries and Heleen Groenenberg, 'Indicators for energy security', Energy Policy 37:6 (2009), pp. 2166-2181; Benjamin K Sovacool and Ishani Mukherjee, 'Conceptualizing and measuring energy security: A synthesized approach', Energy, 36:8 (2011), pp. 5343-5355.

${ }^{16}$ Lynne Chester, 'Conceptualising energy security and making explicit its polysemic nature', Energy Policy 38:2 (2010), pp. 887-895; Christian Winzer, 'Conceptualizing energy security', Energy Policy 46 (2012), pp. 36-48.

${ }^{17}$ Christopher S. Browning and Matt MacDonald, 'The Future of Critical Security Studies: Ethics and the Politics of Security', European Journal of International Relations 19:2 (2013), pp. 235-255; Gavin Bridges, 'Energy (in)security: world-making in an age of scarcity', The Geographical Journal 181:4 (2015), pp. 328-339.
} 
Ciută makes precisely this point in his critical analysis of different concepts of energy security in which he identifies both a logic of war, which closely aligns with the Copenhagen School focus on existential threats to survival, and a logic of subsistence. ${ }^{18} \mathrm{He}$ argues that the latter is not defined by, "the imperative to survive", but instead, "by the functional demands of various sectors of activity, which means its absence does not lead to extinction, but to dysfunction". ${ }^{19}$ These logics involve quite different types of security claims that are part of a more general distinction between security and risk. While there are also arguably different conceptions of risk, a broad distinction can be drawn between security threats that are immediate and urgent, and risks that are longer-term, based on uncertain and more diffuse dangers. $^{20}$

In a constructive 'philosophical' critique of the Copenhagen School, ${ }^{21}$ Corry separates these logics into distinctive processes of securitisation and riskification, in which the former is based on direct causes of harm that

\footnotetext{
${ }^{18}$ Felix Ciută also identifies a third logic of 'total' or 'banal' security in which energy security potentially means the security of 'everything', 'everywhere' and 'against everything' which is an important debate that is beyond the scope of this article. 'Conceptual Notes on Energy Security: Total or Banal Security?', Security Dialogue 41:2 (2010), pp. 123-144 (p.135).

${ }^{19}$ Ibid., p. 132.

${ }^{20}$ Didier Bigo, 'Security and Immigration: Toward a Critique of the Governmentality of Unease', Alternatives: Global, Local Political 27 (supplement) (2002) pp. 63-92; Rens Van Munster, Securitizing Immigration: The Politics of Risk in the EU (London: Palgrave Macmillan, 2009).

${ }^{21}$ For an explanation of the philosophical-sociological distinction which has come to typify securitisation studies, see Thierry Balzacq, 'A theory of securitisation: origins, core assumptions, and variants', in Thierry Balzacq (ed) Securitization Theory: How Security Problems Emerge and Dissolve (London: Routledge, 2010a), pp. 18-28.
} 
threaten the survival of a referent object, while the latter is based on indirect causes of harm that put the governability and resilience of a referent object at risk. While both processes begin with security speech acts, they take different forms. They are based on alternative constructions of the kind of threat, the values to be protected, and the nature of the response to these threats. Instead of leading to measures aimed at eliminating or severely curtailing an existential threat, Corry argues that riskification tends to lead to "programmes for permanent changes aimed at reducing vulnerability and boosting governance-capacity of the valued referent object itself". ${ }^{22}$

Such a philosophical distinction between logics of securitisation and riskification would appear to be particularly well suited for examining energy security because, as even a cursory glance at the literature on energy security reveals, many of the claims about security are about risks rather than threats. ${ }^{23}$ However, adopting a sharp distinction between logics of securitisation and riskification is not without its problems. It runs into some of the same issues with essentialism found in a classic Copenhagen School framework by positing 'risk' as a unified and rule-bound logic which neglects questions of how risks, like security threats, are constructed within

\footnotetext{
${ }^{22}$ Corry (2012), p. 248.

${ }^{23}$ See also Edward Stoddard, 'A Common Vision of Energy Risk? Energy Securitisation and Company Perceptions of Risk in the EU', Journal of Contemporary European Research 8:3 (2012), pp. 340-366.
} 
particular cultures over time $\mathrm{e}^{24}$ and are themselves subjected to contestation and adaptation in concrete empirical circumstances. It also brackets the question of whether a logic of riskification can be 'intensified' into a logic of securitisation or vice versa. ${ }^{25}$ Nonetheless, it has clear methodological advantages, as a set of ideal types for identifying different claims about security and their implications for political practice in particular situations. ${ }^{26}$ When comparing the construction of security across cases rather than engaging in a more contextualised examination of a single case, such a simplification is both desirable and necessary.

The second limitation of the Copenhagen School framework is its excessively textual understanding of (in)security, that neglects the important role that contextual factors can play in shaping the form, dynamics and outcomes of securitisation processes. ${ }^{27}$ As various researchers on the socalled 'sociological' wing of securitisation studies have argued, processes of securitisation and riskification do not occur in a vacuum, but instead within the context of established power relations and institutional structures, which

\footnotetext{
${ }^{24}$ Karen Lund Petersen, 'Risk analysis-A field within security studies?' European Journal of International Relations 18:4 (2012), pp. 693-717.

${ }^{25}$ Michael C. Williams, 'The continuing evolution of securitization theory', in Thierry Balzacq (ed) Securitization Theory: How Security Problems Emerge and Dissolve (London: Routledge, 2010), pp. 216-218; Rens van Munster, 'Logics of Security: The Copenhagen School, Risk Management and the War on Terror', Syddansk Universitet Political Science Publications 10/2005.

${ }^{26}$ Franziskus von Lucke, Zehra Welmann and Thomas Diez, 'What's at Stake in Securitising Climate Change? Towards a Differentiated Approach', Geopolitics 19:4 (2014), pp. 857-884.

27 Balzacq (2010a); Matt McDonald, 'Securitization and the Construction of Security', European Journal of International Relations 14:4 (2008), pp. 563-587.
} 
can enable or constrain the form and process of construction, as well as policy responses. ${ }^{28}$ These factors define the pre-established 'normal' politics of an issue, shaping the specific way in which attempts to reconstruct those issues in terms of security or risk will play out. Such a critique is particularly relevant for energy issues, where it is possible to identify two sets of contextual factors that affect the treatment of energy as a 'normal', 'risk' or 'security' issue - technical and political-economic factors

At the technical level, energy systems of any polity are complex; an assemblage of a particular mix of fuels in overall consumption and electricity production, the sources of these supplies (imported/domestic), established roles for particular types of energy in particular economic sectors, and a configuration of physical infrastructure including the capacity to import, produce and transmit. Major changes to any aspect of this assemblage will generally be very difficult, time-consuming and expensive, often requiring the construction of new generation and/or transit

\footnotetext{
${ }^{28}$ Balzacq, (2010a), pp. 11-15; Thierry Balzacq 'Enquiries into methods: a new framework for securitization analysis', in Thierry Balzacq (ed) Securitization Theory: How Security Problems Emerge and Dissolve (London: Routledge, 2010b), pp. 36-37. Context in this sense is external to the process of securitisation, in contrast to the thick contextualist approach set out by Felix Ciută which focuses on contextualised meanings of security, 'Security and the problem of context: a hermeneutical critique of securitisation theory', Review of International Studies 35:2 (2009), pp. 301-326.
} 
infrastructure. ${ }^{29}$ As a result, these technical factors are liable to produce strong path-dependent effects that shape and constrain future actions. ${ }^{30}$

At the political-economic level, energy is produced, traded and used under certain conditions that are regulated by state actors engaged in different levels and forms of market intervention. These conditions constitute the "rules of the game" that structure the interactions of different actors. ${ }^{31}$ Various typologies within Energy Studies draw distinctions between different forms of energy governance in particular states or regions such as, 'liberalism' and 'geopolitics', 'economic liberalism' and 'resource nationalism, ${ }^{32}$ 'liberal' and 'state' capitalism, ${ }^{33}$ or 'markets and institutions' and 'regions and empires'. ${ }^{34}$ Subtly different emphases aside, in all cases the

\footnotetext{
${ }^{29}$ Ivan Scarse and Gordon MacKerron, 'Lock-in', in Ivan Scarse and Gordon MacKerron (eds.) Energy for the Future: A New Agenda (Basingstoke: Palgrave Macmillan, 2009).

${ }^{30}$ Major changes are not impossible: the energy systems of the UK and Poland have undergone important changes in recent decades, and several advanced economies are currently attempting a transition to lower-carbon energy systems, most notably Germany. The core point is that such changes are difficult, expensive and time-consuming. For more on energy transitions see Vaclav Smil, Energy Transitions: History, Requirements, Prospects (Santa Barbara, CA: Prager, 2010).

31 Caroline Kuzemko, Michael F. Keating and Andreas Goldthau, The Global Energy Challenge: Environment, Development and Security (London: Palgrave, 2016), p. 58. See also Andrei V. Belyi and Kim Talus (eds.) States and Markets in Hydrocarbon Sectors (Basingstoke: Palgrave Macmillan, 2015).

32 Ian Bremmer and Robert Johnston, 'The Rise and Fall of Resource Nationalism', Survival 51:2 (2009), pp. 149-158; Francis McGowan (2008) 'Can the European Union's Market Liberalism Ensure Energy Security in a Time of 'Economic Nationalism'?', Journal of Contemporary European Research, 4:2 (2008), pp. 90-106.

${ }^{33}$ Wojciech Ostrowski, 'State Capitalism and the Politics of Resources', in Andrei V. Belyi and Kim Talus (eds.) States and Markets in Hydrocarbon Sectors (Basingstoke: Palgrave Macmillan, 2015), pp. 83-102.

${ }^{34}$ Aad F. Correljé and Coby van der Linde, 'Energy Supply Security and Geopolitics: A European Perspective', Energy Policy 34:5 (2006), pp. 532-543. Many have pointed to the role that states have come to play in national and global energy governance. See Navorz K.
} 
main distinction that most researchers draw is between market-led and stateled systems of energy governance. ${ }^{35}$

Market-led governance is based on a deregulated market-based system of energy production, trade and consumption. Under this approach, market participants are the primary actors, which are expected to ensure supply reliability with minimal involvement or oversight from government actors. These actors are granted considerable autonomy, and in most cases are wholly or predominantly private entities. ${ }^{36}$ State-led governance, by contrast, is based on the subservience of markets to the political objectives of the state. Governments are the primary actors, not only involved in regulating market conditions, but also exercising substantial influence and control over the actions of market participants.

Although technical and political-economic factors are both likely to play a role in any attempt at constructing energy as a security issue, their relative importance in enabling and constraining securitisation or riskification will differ. We expect that although technical factors can act as constraints on possible material changes to energy systems, particularly in the short-term,

Dubash and Ann Florini, 'Mapping Global Energy Governance', Global Policy 2:s1 (2011), pp. 6-18.

${ }^{35}$ To be clear, these modes of energy governance are ideal types. They nonetheless represent two extremes on the full spectrum of political-economic conditions in the various EU Member States, even if certain systems may be marked by characteristics of both a market-led and state-led system.

${ }^{36}$ Governments may maintain part ownership of particular market participants under this system, but will usually not be the majority shareholder and will not direct the actions of the company in question. 
they will primarily function as resources for actors' claims about the (lack of) security within a polity. 'High dependence' or 'high consumption' do not automatically mean that energy will be securitised or riskified - this will depend on whether actors discursively construct these factors as 'existential threats' or 'risks'. The task of the analyst should therefore be to identify whether an intersubjective understanding of these technical factors emerges among actors involved in energy governance, or whether different understandings emerge between different groups.

Political-economic factors on the other hand could be much more decisive in whether energy issues can be securitised or riskified. As noted above, such factors structure the actions and interactions of the actors involved in energy governance. As such, they define what constitutes 'normal' energy politics in a particular spatial and temporal context. Across the EU Member States for instance, there are a range of modes of energy governance ranging from market-led to state-led. This does not mean that these structures are deterministic or cannot change; indeed constructing energy as a security issue is one such way in which the normal 'rules of the game' can be changed. However what securitisation and riskification mean cannot be separated from the particular political-economic circumstances in which they emerge. In particular, we expect that market-led and state-led energy governance will be amenable to the logics of securitisation and riskification to differing degrees. 
While securitisation is possible in market-led systems, it would require fundamental changes that would undermine the basis of a liberal market. It would involve major levels of Government intervention and the central coordination of market participants' activities, subordinating the market to the achievement of political objectives. In short, it is the antithesis of a liberal approach and would involve a radical shift from a market-led to a state-led system of energy governance. In a state-led system, securitisation is more likely because the state already tends to direct the energy system in the pursuit of other goals, and the adoption of exceptional measures to eliminate an existential threat does not undermine the economic foundations of the system of governance. ${ }^{37}$ While riskification could occur under either political-economic system in principle, we expect it to be more likely under market-led systems. Although major Government interventions would undermine such systems, selective interventions focused on improving resilience may be permissible as a means of preserving the autonomy of market participants and the functioning of a liberal market. By steering energy companies to take Government identified risks into account in their normal market activities, this can allow market failures to be addressed through primarily market-based means. This kind of riskified governance

\footnotetext{
37 The Copenhagen School themselves make fundamentally the same point: "Whereas economic nationalists have no problem invoking economic security in state terms, liberals are (or should be) constrained from doing so by their commitment to efficiency and thus to openness and competition. In principle, this commitment should exclude from securitization a great range of things that might count as serious economic or political issues" (Buzan, et al. 1998, p. 105).
} 
would certainly involve greater levels of government influence, but without completely subordinating the market to the political objectives of the state.

\section{Research Design and Methods}

Taken together, these twin critiques of the Copenhagen School point to the need for taking different logics of security and how these may be shaped by contextual conditions seriously. In this article we respond to this need through an analysis of constructions of gas as a security issue in two EU Member States - the UK and Poland. This analysis is based around two research questions. First, has gas been constructed as a security issue and, if so, what form do those constructions take? Second, have technical and economic factors played a role in shaping these attempts to construct gas as a security issue?

To address these questions, we focus on the time period in which concerns about energy security became prominent in the EU, 2006 to 2015. While it is common to focus on shorter 'moments' of exceptional discursive claims in securitisation analyses, we start from the premise that the construction of a security issue can also be an iterative, gradual process. ${ }^{38}$ This allows us to examine whether particular discourses and the policies that are enabled by them have become institutionalised and widely accepted or not.

\footnotetext{
${ }^{38}$ Matt MacDonald, 'Securitization and the Construction of Security', European Journal of International Relations, 14:4 (2008), pp. 563-587.
} 
While the analysis of all EU Member States would allow us to fully gauge the level of intersubjective agreement about the kind of security concern gas is, this is not possible in the space of a single article. Instead, we begin by providing a brief overview of the major discursive and governance changes at the EU level in order to contextualise developments in the Member States. We then proceed to analyse two Member States case studies that we have chosen as exemplars of the very different systems of energy governance which currently exist among the Member States, and whose Governments have repeatedly and frequently expressed concerns about energy security over at least the past decade.

In both cases, we focus on gas for two reasons. Gas has been the main focus of most claims about energy (in)security across Europe. Excluding other energy sources from our analysis also allows a narrower focus on the two contextual conditions identified above which, we argue, have the greatest role to play in shaping security constructions. At the technical level, we assess the relative share of gas in the energy and electricity production mixes of these Member States, and levels of dependence on particular routes or sources of gas supplies. At the economic level, we assess the respective roles of government and market actors in implementing governing gas supplies and responding to shifting security evaluations.

The analysis of each Member State involves tracing how energy has been presented as a security issue in official discourse, how durable these 
constructions have been over time, and what the relative influence of contextual factors is in each case. In each empirical section, we analyse changes in discourse and modes of energy governance separately, which allows us to analytically distinguish their effects and to account for their interaction. Across these two sections, we utilise a wide range of primary data in the form of publically available government and EU policy documents and statistics, speeches by prominent actors, reports by government agencies, and secondary literature by country and issue area experts. ${ }^{39}$ For the purposes of tracing discursive change, we focus on elite sources because the energy sector is relatively closed and technocratic in comparison to other sectors, which means that the authority to 'speak security' is largely confined to government elites and market participants, rather than requiring the explicit agreement of wider audiences.

\section{Constructing an Energy Union}

From its original guidelines on a European energy policy to the Energy Union proposal, the Commission has long sought to base a common energy policy on the twin objectives of ensuring, "security of supply at prices

\footnotetext{
${ }^{39}$ Polish documents are official government translations into English. All national security strategies, energy policies and relevant regulator documents from 2000-2016 were analysed, the Factiva database was used to trace the discourse of key energy actors during this time period.
} 
which are relatively stable and as low as possible". ${ }^{40}$ These objectives have been supplemented since the 2000 s by a third objective of sustainability and climate change policy. ${ }^{41}$ Prior to 2006 , the Commission had already begun to speak of energy in terms of risks to the security of supplies. In 2000 it released a green paper on the security of energy supplies in which it framed growing dependence as a "structural weakness", ${ }^{2}$ which made the EU vulnerable to any supply disruptions. ${ }^{43}$ Such tentative moves into security discourse were not about urgent and existential threats, but about potential supply risks. $^{44}$

Two major gas supply disruptions, in 2006 and 2009, acted as catalysts for the Commission to repeatedly portray supplies as insecure. Following the initial disruption, the language of risk featured increasingly prominently, with the Commission warning in its 2007 white paper that the "risk of supply failure is growing". ${ }^{45}$ In 2008 the Commission argued that:

\section{"A number of Member States are overwhelmingly dependent on one single supplier [for gas]. Political incidents in supplier or}

\footnotetext{
${ }^{40}$ Commission, 'First guidelines for a Community energy policy', COM(68)1050, 18 December 1968, p. 7; Commission, 'Energy Union Package', COM(2015)80, 25 February 2015, p. 1.

41 Tomas Maltby, 'European Union energy policy integration: A case of European Commission policy entrepreneurship and increasing supranationalism', Energy Policy 55 (2013), pp. 435-444.

${ }^{42}$ Commission, 'Green Paper. Towards a European strategy for the security of energy supply’, $\operatorname{COM}(2000) 769,29$ November 2000, p. 2; p. 46.

43 ibid. pp. 75-77.

${ }^{44}$ Commission, 'The internal market in energy: Coordinated measures on the security of energy supply', COM(2002)488, 11 September 2002, p. 51.

${ }^{45}$ Commission, 'An Energy Policy for Europe', COM(2007)1, 10 January 2007, p. 4.
} 
transit countries, accidents or natural disasters, the impacts of climate change, remind the EU of the vulnerability of its immediate energy supply." ${ }^{46}$

Such attempts to securitise, or more accurately riskify gas, can only be understood in the context of the different modes of energy governance in the EU's Member States, and the Commission's attempts to reshape these in a more liberalised and integrated direction. Traditionally, Member States have pursued energy policies in relative isolation from each other and in most cases have had to rely on nationally negotiated deals to import gas from non-EU countries due to a lack of domestic gas production. ${ }^{47}$ The reliability and availability of supplies was generally achieved through stable long-term contracts, joint ownership and financing of long-distance transit pipelines, prices determined by oil-indexation rather than market dynamics, and national restrictions on the final destination of the commodity. Under this arrangement both consumers' security of supply and producers' security of

\footnotetext{
${ }^{46}$ Commission, 'Second Strategic Energy Review: An EU Energy Security and Solidarity Action Plan', COM(2008)781, 13 November 2008, p. 3.

${ }^{47}$ Such deals usually involved state-owned or private importers negotiating deals with suppliers, supported by intergovernmental agreements between supplier and consumer states. See Javier Estrada, et al., Natural Gas in Europe: Markets, Organization and Politics (London: Pinter Publishers, 1988).
} 
demand was ensured through stable and predictable contracts, creating a mutual interdependence. ${ }^{48}$

The Commission has consistently promoted the idea of an alternative: A single internal gas market premised on the development of a liberalised and competitive market for gas in which short-term trades are possible, prices are primarily based on the dynamics of supply and demand, and movement of supplies across the EU is unrestricted. While this undermines the traditional model of security, the objective is increased security of supply through greater diversification, increased interdependence between Member States, and a reduction in the potential for supply disruptions to cause interruptions to customer supplies. ${ }^{49}$ In short, the Commission's efforts to develop an internal gas market have been an attempt to construct a sector in which the role of the state is to set limited regulatory conditions and only intervene in cases of market failure; a distinctly liberal approach to the security of supplies premised on integrationist principles.

In 2006 the basic building blocks of such an approach were already in place, following the passage of the first and second packages of internal market legislation. ${ }^{50}$ The 'Third Package' adopted in 2009 involved more market

\footnotetext{
${ }^{48}$ Pami Aalto, 'States and Markets in Energy Policy' in Andrei V. Belyi and Kim Talus, (ed.) States and Markets in Hydrocarbon Sectors (Basingstoke: Palgrave Macmillan, 2015), pp. 40-60.

${ }^{49}$ Filippos Proedrou, EU energy security in the gas sector: evolving dynamics, policy dilemmas and prospects (Ashgate: Farnham, 2012), p. 61.

${ }^{50}$ Directive 98/30/EC; Directive 2003/55/EC.
} 
regulation; to ensure the separation of gas transmission from other activities to prevent cross-subsidy and anti-competitive practices among previously integrated companies. ${ }^{51}$ Other gas legislation has, in most cases, been significantly based on a liberal market approach, including the prioritisation of efforts to liberalise energy markets through the Third Energy package. For instance, the adoption of legislation for the prevention and management of supply disruptions in $2010^{52}$ was explicitly premised on a hierarchy of intervention in which market participants would be allowed to respond in the first instance, with recourse to national governments or coordinated EU level action only in extreme circumstances. The Commission has been more actively involved in funding gas infrastructure, particularly reverse flows on existing pipelines to enable the mitigation of supply disruptions, though this has involved relatively minor investments. ${ }^{53}$ The Commission has extended its role regarding intergovernmental agreements for the supply of gas; as part of its Energy Union proposals it has sought a greater, ex ante and participatory role. ${ }^{54}$ This is a rare exception to a strictly liberal approach, along with the EU-Russia Early Warning mechanism for gas supply disruptions.

\footnotetext{
${ }^{51}$ Directive 2009/73/EC.

${ }^{52}$ Regulation 994/2010.

${ }^{53} € 2.3$ bn between 2007-2013. See European Court of Auditors, 'Improving the security of energy supply by developing the internal energy market: more efforts needed', SR16/2015 (2015), p. 15.

${ }^{54}$ Commission, 'Proposal for...establishing an information exchange mechanism with regard to intergovernmental agreements and non-binding instruments between Member States and third countries in the field of energy', Brussels, 16 February 2016, $\operatorname{COM}(2016)$ 53 final.
} 
As Goldthau and Sitter argue, the Commission can be described as a "mostly" liberal actor. ${ }^{55}$ However, this does not mean that EU energy policy as a whole can be described as market-led. On the contrary, progress towards achieving gas market objectives has been slow, with liberalisation developing at different paces and to different levels in each Member State. ${ }^{56}$ Both historically and in the present day, different Member States continue to conform more closely to either the state-led or market-led modes of energy governance.

In summary, the Commission has long been a riskifying actor, framing gas supplies as threatened by growing dependence and associated risks, most notably of supply disruptions which affect multiple Member States and the EU as a whole. It has consistently promoted a predominantly liberal approach to ensuring and improving the security of gas supplies, advocating an approach in which the state has a limited role except in ensuring market functioning.

\section{United Kingdom}

Prior to the Commission's initial attempts to develop a liberalised and integrated gas market, the UK's approach to energy governance had already

\footnotetext{
${ }^{55}$ Andreas Goldthau and Nick Sitter 'A liberal actor in a realist world? The Commission and the external dimension of the single market for energy', Journal of European Public Policy, 21:10 (2014), pp. 1452-1472.

${ }^{56}$ European Court of Auditors (2015); Samuel R. Schubert, Johannes Pollak and Maren Kreutler, Energy Policy of the European Union (London: Palgrave, 2016), pp. 157-65.
} 
undergone a period of radical transformation in the 1980s and 1990s towards less state intervention. ${ }^{57}$ Key aspects of this transformation were a systematic withdrawal of the state from gas and wider energy policy, the privatisation of state energy companies, the dissolution of the Department of Energy in 1992, the transfer of residual policy functions to the Department of Trade and Industry (DTI) and the establishment of independent regulators for electricity and gas. Privatised companies and other market participants filled the gap left by the withdrawal of the state, taking on the responsibility of ensuring the availability and reliability of supplies. Although this process was one component of a broader trend towards deregulation and privatisation across the UK economy under successive Conservative and Labour governments, ${ }^{58}$ it was enabled by the UK's lack of reliance on external sources of gas due to considerable domestic energy reserves and production.

The UK gas sector did, however, go through two important transitions at the technical level in the years prior to the period examined in this study. First, gas production peaked in 2000, leading to the UK becoming a net importer of gas in 2004. This largely coincided with the UK also becoming a net

\footnotetext{
${ }^{57}$ Florian Kern, Caroline Kuzemko and Catherine Mitchell, 'Measuring and explaining policy paradigm change: the case of UK energy policy', Policy \& Politics 42:4 (2014), pp. 513-530.

${ }^{58}$ Ian Rutledge, 'UK Energy Policy and Market Fundamentalism: a Historical Overview', in Ian Rutledge and Philip Wright, (eds.) UK Energy Policy and the End of Market Fundamentalism (Oxford: Oxford University Press, 2010).
} 
importer of oil and energy as a whole, which amounted to a major structural transformation in the UK energy system. Second, in preparation for this transition, the UK gas market ended its market isolation in 1998, following the construction of a pipeline to Belgium. This was eventually followed by further pipeline and LNG terminal developments in the early 2000s. ${ }^{59}$

\section{Discourses of gas insecurity}

Prior to 2006, gas and other energy supplies were both depoliticised and desecuritised in the UK. Even when it became apparent that the UK was set to become a net importer, the security of gas supplies was not called into question. Most notably, when the Government issued its white paper on Energy in 2003, the first in more than a decade, the importance of 'maintaining reliability' was emphasised, rather than any need to respond to emergent risks or threats. ${ }^{60}$ Any risks to the security of supplies were described as "manageable" ${ }^{, 61}$ and the prospect of greater import dependence was framed in terms of an unproblematic 'interdependence' with external suppliers. ${ }^{62}$ Such confidence in the security of supplies was also evident in

\footnotetext{
${ }^{59}$ See Rutledge (2010) and Francis McGowan 'The UK and EU Energy Policy: From Awkward Partner to Active Protagonist?', in Vicki L. Birchfield, and John, S. Duffield, (eds.) Toward a Common European Union Energy Policy: Problems, Progress and Prospects (Basingstoke: Palgrave Macmillan, 2011b), pp. 187-213.

${ }^{60}$ Department of Trade and Industry (DTI), 'Our energy future - creating a low carbon economy’, Cm 5761, February 2003, p.9, pp. 76-94.

${ }^{61}$ ibid., p. 76.

${ }^{62}$ ibid., p. 78.
} 
various other government evaluations from the time. ${ }^{63}$ It was underscored by the belief that, "markets are likely to deliver energy reliability most costeffectively", ${ }^{64}$ and that the role of the state should be to monitor these markets for any potentially threatening developments, while promoting liberalisation and 'good governance' abroad. In contrast, climate change as a consequence of continuing to use fossil fuels was explicitly considered a major threat, to be addressed through a transition to low carbon energy sources. $^{65}$

Although UK supplies were not affected by the January 2006 disruption a discourse of gas supply insecurity nonetheless began to emerge at this time. At the broadest level, the security of energy supplies was elevated to parity with climate change as one of the two main objectives of UK energy policy, and as a source of potential threats and risks. ${ }^{66}$ Gas supplies were singled out as a major source of potential risks, ${ }^{67}$ associated primarily with a need to ensure adequate levels of investment in new infrastructure to replace declining domestic gas production with sufficient pipeline and liquefied gas

\footnotetext{
${ }^{63}$ See, for instance, the reports of the Joint Energy Security of Supply (JESS) working group from this period.

${ }^{64}$ DTI (2003), p. 88.

${ }^{65}$ DTI (2003), p. 6, pp. 44-62.

${ }^{66}$ DTI, 'The Energy Challenge: Energy Review Report 2006', Cm 6887, July 2006, pp. 1011.

${ }^{67}$ Echoed by the Prime Minister - "in the future energy security will be almost as important as defence in the overall security of a country's interests". Tony Blair cited in Mark Milner, 'Energy: New pipeline: Gas essential to British security, says Blair', The Guardian, 17 October 2006.
} 
capacity for importing supplies. ${ }^{68}$ The degree of discursive change should not, however, be overstated. Statements about the security of supplies invariably took the form of highlighting potential rather than urgent risks or threats. The 2007 white paper on energy states that "imports are not in themselves a threat to security of supply [but] bring new associated risks". ${ }^{69}$ The potential for supply disruptions affecting the UK was considered unlikely before the mid-2010s. The real 'risk' was a lack of competitive markets on the main gas supply routes to the UK rather than rising import dependence specifically. ${ }^{70}$

This discourse persisted following the 2009 gas supply disruption, although disagreements began to emerge about how to evaluate potential threats. In the first white paper produced by the newly established Department for Energy and Climate Change (DECC) the same discourse of potential risks present before the disruption was largely reproduced. It was emphasised that, "the immediate risks to UK security of supply were extremely low", and that, "[t]he UK's diverse sources of gas imports meant that we experienced little direct effect". ${ }^{71}$ In contrast, the 2009 'Wicks Report'

\footnotetext{
${ }^{68}$ DTI (2006), pp. 86-87.

${ }^{69}$ DTI, 'Meeting the Energy Challenge: A White Paper on Energy', Cm 7124, May 2007, p. 107.

${ }^{70}$ DTI (2006), p. 77.

71 Department of Energy \& Climate Change (DECC) 'The UK Low Carbon Transition Plan: National strategy for climate and energy’, 15 July 2009, p. 106.
} 
framed rising import dependence as an issue of "geopolitical security" 72 and issued stark warnings about "significant negative economic impacts" that could arise from gas supply disruptions. ${ }^{73}$ While it was argued in the white paper that security should continue to be left to the market, the Wicks Report insisted that it was crucial that the UK, "retains independence in its foreign policy through avoiding dependence on particular nations". ${ }^{74}$ The Conservative Party was highly critical of the Labour Government's energy policy in the lead up to the 2010 election, highlighting growing import dependence and declining electricity capacity margins as 'major threats' to energy security. ${ }^{75}$

However, the lack of explicit references to these threats once the Conservative-Liberal Democrat coalition took power and after the formation of the majority Conservative government in 2015, suggests that this was merely electioneering rather than a substantive shift. Indeed, since 2010 the discourse has taken a similar form to the pre-2009 period. Repeated reassurances about the security of gas supplies were combined with statements about potential threats and risks that could emerge in the future.

\footnotetext{
72 Malcolm Wicks, 'Energy Security: A national challenge in a changing world', Department of Energy and Climate Change, August 2009, p. 8.

${ }^{73}$ Ibid., p. 44.

${ }^{74}$ Ibid., p. 8.

${ }^{75}$ Conservative Party 'Rebuilding Security: Conservative Energy Policy for an Uncertain World', Policy Green Paper 15:4 (2010). This view was not shared by their eventual coalition partners in their manifesto and public statements (Liberal Democrats, 'Liberal Democrat Manifesto 2010'). The coalition agreement between the two parties upon forming the new government in 2010 made no mention of energy security threats (UK Government, 'The Coalition: our programme for government', Cabinet Office, May 2010).
} 
Each Annual Energy Statement and Security of Supply report presented to Parliament offered reassurances that the UK has, "the most liquid and one of the largest gas markets in Europe with extensive import infrastructure and a diverse range of gas supply sources". ${ }^{76}$ Meanwhile the risks that these documents refer to are all potential rather than immediate. For instance:

"The outlook for security of gas supply is broadly benign in the near term. This does not mean that it is risk-free; there are risks, both in the short-term and towards the second half of the decade when some uncertainties remain". ${ }^{77}$

Far from increasing the intensity of threat constructions, Government discourse since 2010 has gradually adopted a less securitised tone. The government stated in its 2013 Annual Energy Statement that the, "security of gas supply is expected to be robust in the short, medium and long term",78 while the following year it reassured Parliament that the UK gas system was, "capable of responding flexibly to changing market conditions...[as]

\footnotetext{
${ }^{76}$ DECC and Ofgem, 'Statutory Security of Supply Report', HC675, 31 October 2013, p. 8. Similar statements are found in the DECC 'Annual Energy Statement', Cm 8456, November 2012a, DECC 'Annual Energy Statement 2014', Cm8945, October 2014, p. 41, and DECC and Ofgem, 'Statutory security of supply report 2015': HC 482, 25 October 2015 , p. 11.

${ }^{77}$ DECC and Ofgem, 'Statutory Security of Supply Report', HC542, November 2010, p. 41. Evident in all joint DECC and Ofgem reports on the security of gas supplies during the lifetime of the coalition government (DECC and Ofgem, 'Statutory Security of Supply Report', HC1604, 8 November 2011; DECC and Ofgem, 'Statutory Security of Supply Report', HC688, 29 November 2012; DECC and Ofgem, 'Statutory Security of Supply Report', HC675, 31 October 2013; DECC and Ofgem, 'Statutory Security of Supply Report', HC686, 28 October 2014).

${ }^{78}$ DECC, 'Annual Energy Statement 2013', Cm8732, October 2013b.
} 
has been well demonstrated in recent years in a range of challenging circumstances". ${ }^{79}$ Following Russia's annexation of Crimea in 2014, the government reported the results of stress tests, which concluded that even in the event of a "full cessation of Russian gas supplies into Europe for an entire winter", UK gas supplies would not be disrupted. ${ }^{80}$

Kuzemko has argued that following a prior depoliticisation of energy policy there has, since the late-2000s, been a qualified re-politicisation of energy policy in the UK. It is argued that this is "partly through the impact of [emerging] narratives of national energy supply (in-)security", so speech acts and the discursive construction of security contributing in turn to greater, though still limited, energy policy steering by the government. ${ }^{81}$ Although a discourse of insecurity has emerged in the UK, we argue that it most clearly follows a logic of riskification rather than securitisation. Such a discourse has been relatively consistent throughout the entire 2006-2015 period, with the government continually evaluating and reporting on risks to gas supplies in contrast to the period prior to this. Moreover, aside from some alarmist statements in 2008-2010, these evaluations of the level of 'risk' have generally been favourable but not benign. Indeed, gas supplies are now frequently portrayed as a means of increasing the security of UK

\footnotetext{
${ }^{79}$ DECC (2014), p. 58.

${ }^{80}$ DECC and Ofgem (2014), pp. 48-49.

${ }^{81}$ Caroline Kuzemko, 'Politicising UK energy: what 'speaking energy security' can do', Policy \& Politics, 42:2 (2014), pp. 259-74.
} 
energy supplies more generally, as a reliable low-carbon backup for renewables and as a major part of the energy mix, rather than as a threat to 'energy security'. ${ }^{82}$ This indicates that both that riskification has occurred and that there are few signs of any transition to a more securitised discourse in the near future.

\section{Energy governance}

Discursive changes within the UK must be understood in relation to the structural change from a net exporter to a net importer of gas. Almost all energy policy documents make reference to this fact. Nonetheless, it would be inaccurate to view the emergence of a discourse of gas supply insecurity as a simple result of such changes at the technical level. The initial discursive changes began several years after this transition was well known, in the late 1990s. Moreover, throughout the period examined above, gas supply discourse did not contain claims about imminent or urgent threats despite dependence on imported gas expanding from zero in 2003 to $45 \%$ by 2014 and gas continuing to occupy a prominent role in the UK energy mix. This lack of congruence between increased dependence and discursive change rules out a simple causal relationship. Where the transition had an effect is in providing the economic rationale for investment decisions taken by the private sector to construct pipelines for importing alternative supplies

\footnotetext{
${ }^{82}$ DECC Energy Security Strategy, Cm8466, November 2012b; DECC, Gas Generation Strategy, Cm8407, December 2012c.
} 
to the UK market in anticipation of the decline of North Sea production. ${ }^{83}$ This enabled the UK to retain gas as a major component of its energy mix, established connections to other EU markets for the first time and opened the UK to international LNG markets. The security of UK gas supplies was then no longer shaped solely by domestic developments and the reliability of what was its only external supplier, Norway, but also by developments in continental Europe and beyond.

On the other hand, the fact that gas was such an important part of the UK's energy mix prior to the transition, including in the generation of electricity, meant that there were strong economic incentives to source new supplies and significant economic barriers to investing in alternative energy sources and network infrastructures. Gas has retained a major role in the energy mix as a result, even as overall UK energy consumption declined from 2005 onwards. The share of gas in UK energy consumption expanded slightly between 2005 and 2010, from $37 \%$ to $40 \%$, before dropping to $28 \%$ in 2014, its lowest level since the 1990s. In 2014, gas still accounted for nearly a third of the electricity generated in the UK. ${ }^{84}$

More important than changes at the technical level have been the presence and preservation of a market-led approach to energy governance.

\footnotetext{
83 These included the Interconnector which opened in 1998 and BBL which opened in 2006.

${ }^{84}$ DECC, 'Digest of United Kingdom Energy Statistics 2015', 30 July 2015.
} 
Throughout this period, decisions continued to be taken by private companies, highlighting that in terms of energy governance the UK gas market remains one of the most liberalised and least concentrated in the EU, with eight companies active in the supply or import of gas. Successive UK Governments have routinely called for the further liberalisation of European gas markets and the development of open market and 'good governance' principles in states supplying energy to international markets. ${ }^{85}$ Governments also resisted the temptation to directly intervene in the market by, for instance, developing strategic (rather than commercial) gas storage, arguing that this would be unduly expensive and could interfere with incentives for private companies to invest in such infrastructure as needed. ${ }^{86}$ In 2015, the Energy Secretary stated that "We know competition works. It keeps costs low and can deliver a clean and reliable energy system". ${ }^{87}$ The objective was "allowing markets to flourish". 88

While the market-led approach has not been displaced, faith in its ability to deliver security has increasingly been called into question. Some institutional and policy developments in recent years suggest that the UK has heeded Wicks' dire warning that, "[t]he time for market innocence is

\footnotetext{
${ }^{85}$ DTI (2003), p. 78; DTI (2006), pp. 81-82; DTI (2007), p. 36; DECC (2012a), p. 21.

${ }^{86}$ DTI (2006), pp. 89-90; DECC (2013a), p. 4; DECC and Ofgem (2013), pp. 44-46.

${ }^{87}$ Amber Rudd, 'New Direction for UK energy policy', UK Government, 18 November 2015, available at: \{https://www.gov.uk/government/speeches/amber-rudds-speech-on-anew-direction-for-uk-energy-policy\} accessed 2 May 2016.

${ }^{88}$ Kiran Stacey and Pilita Clark, 'Questions over Rudd push to generate more power from gas', Financial Times, 18 November 2015.
} 
over". ${ }^{89}$ The most visible development was the creation in 2008 of a dedicated energy department, DECC, the first such ministry in 26 years. ${ }^{90}$ At its launch the Energy Minister Ed Miliband argued that the government would pursue a "strategic government and dynamic markets" approach in a departure from the "markets-only" approach of the past. ${ }^{91}$ What this meant in practice was that the government would become more active in setting energy policy objectives and playing a greater role in correcting market failures without habitually intervening in the functioning of the markets. In the gas sector specifically, the most visible interventions focused on enabling and incentivising shale gas exploration within the UK. The coalition government established an Office of Unconventional Oil and Gas within DECC in 2013 to support exploration, ${ }^{92}$ then moved this department's functions to a separate Oil and Gas Authority. The Treasury supported this through reducing the tax paid by onshore gas projects (HMRC, 2013), while the Prime Minister actively lobbied the European Commission (with the Polish government) to ensure that exploration and drilling were not restricted by new regulations at the EU level (Cameron, 2013).

\footnotetext{
${ }^{89}$ Wicks (2009), p. 1.

${ }^{90}$ Kern et al. (2014).

${ }^{91}$ Ed Miliband, 'The rise and fall and rise again of a Department of Energy', speech given at Imperial College, London, 9 December 2008.

92 Edward Davey, 'Office of Unconventional Oil and Gas Introductory Event', Chatham House, London, 11 March 2013.
} 
Whether such interventions represent a 'paradigm shift' in UK energy policy is an ongoing subject of debate within Energy Studies, ${ }^{93}$ however it appears that, at least in the gas sector, none of these developments represents a decisive step away from market-led energy governance. Rather, they indicate a more active Government policy in support of an otherwise resilient market-led approach through selective interventions. Although the coalition government became increasingly 'interventionist' regarding the development of shale gas, it was also explicit that it considered there to be "no clear case for a further intervention in the gas market above and beyond the range of measures we are already taking to enhance our gas security". ${ }^{94}$ There is no evidence that this has changed under the majority Conservative government. ${ }^{95}$ Moreover, the transition from a net exporter to a net importer of gas has not resulted in a substantial reduction in the role of gas in the UK energy mix or the emergence of a highly securitised discourse about gas supplies. Instead gas has come to be viewed primarily as a means of ensuring wider energy security rather than as a direct source of threats. Extraordinary measures were not taken and instead government objectives

\footnotetext{
93 Rutledge (2010); Kern et al. (2014); Caroline Kuzemko, The energy security-climate nexus: Institutional change in the UK and beyond (Basingstoke: Palgrave Macmillan, 2013).

${ }^{94}$ DECC, 'Gas Security Policy Framework', 4 September (2013a), p. 4.

${ }^{95}$ Whilst it is beyond the scope of this article, the current Government has become more interventionist outside of the gas sector, such as in its support for new nuclear power capacity.
} 
have been focused on developing the resilience of the UK energy system within a largely liberal market approach.

\section{Poland}

Prior to the late 1980s, Poland was a planned economy and the energy sector was no exception. ${ }^{96}$ There were high levels of state involvement, subsidised energy prices, low levels of energy efficiency and little consideration of the environmental impact of energy use. ${ }^{97}$ Enlargement pressure involved adhering to EU energy market liberalisation, and the 1997 Energy Law Act ${ }^{98}$ paved the way for the transition towards a liberalised and unbundled energy market and the removal of state subsidies. In December 1999 the Ministries of Treasury, Economy and Finance set out energy market liberalisation objectives, ${ }^{99}$ followed by the passage of the 2000 Energy Policy which echoed these. ${ }^{100}$

EU accession had a strong effect on Polish energy policy, but not an unconstrained one. As will be demonstrated, post-accession conditionality

\footnotetext{
96 Beata Radzka, 'Liberalisation, privatisation and regulation in the Polish electricity sector', Privatisation of Public Services and the Impact on Quality, Employment and Productivity (PIQUE) 2006, available at: \{http://www.pique.at/reports/pubs/PIQUE_CountryReports_Electricity_Poland_November 2006.pdf $\}$ accessed 2 May 2016, p. 1.

${ }^{97}$ Mike Bradshaw, Global Energy Dilemmas. (Cambridge: Polity Press 2014), pp. 86-89.

${ }_{98}^{98}$ Poland Energy Act, The Office of Sejm, 10 April 1997.

99 Joanna Kulczycka and Aleksandra Lipinska, 'Barriers to liberalisation of the Polish energy-sector', Applied Energy 76 (2003), pp. 229-238 (p. 229).

100 Polish Government 'Assumptions of Energy Policy to 2020', Ministry of Economy, 2000 .
} 
has been somewhat weaker in that transposition and implementation of EU legislation has at times been slow and frequently delayed. The state has retained ownership of unbundled firms, resisted the development of independent energy regulation, ${ }^{101}$ and delayed price deregulation for households because of concerns about price volatility. ${ }^{102}$

\section{Discourses of gas insecurity}

Prior to the 2006 gas supply disruption there was a distinct lack of securitisation in the gas sector. The 2000 Energy Security Strategy concluded that the "energy safety of the state [...] has not been threatened during the past few years". ${ }^{103}$ The 2003 National Security Strategy only included energy security as an objective of energy policy rather than being subject to explicit threats, ${ }^{104}$ while the Foreign Ministers' annual addresses from this time made no reference to threats or risks to energy nor national

\footnotetext{
${ }^{101}$ Bartlomiej Nowak, 'Challenges of Liberalization: The Case of Polish Electricity and Gas Sector', Yearbook of Antitrust and Regulatory Studies 2:2 (2009), pp.141-168: 143; European Commission (2012) 'Polish Energy Market 2011', available at: $\{\mathrm{http}: / /$ ec.europa.eu/energy/gas_electricity/doc/pl_energy_market_2011_en.pdf\} accessed 3 March 2016, pp. 2-3.

102 RSMI, 'Renewable Energy in Poland', October 2012, available at: $\{\mathrm{http}: / /$ www.rsmi.com/attachments/approved/renewable-energy-in-

poland2/en/RenewableEnergyinPoland_Oct12.pdf\} accessed 2 May 2016: 3; Nilsson, Lars J., Pisarek, Marcin, Buriak, Jerzy, Oniszk-Popawska, Anna, Bucko, Pawel, Ericsson, Karin, Jaworski, Lukasz (2006) 'Energy policy and the role of bioenergy in Poland', Energy Policy 34, pp. 2263-2278: 2270. Most sales on the retail market made by incumbent suppliers which used to be part of the distribution companies before market opening (Commission, 'Polish Energy Market 2011', 2012, available at: $\{\mathrm{http}: / /$ ec.europa.eu/energy/gas_electricity/doc/pl_energy_market_2011_en.pdf\} accessed 3 March 2016, p. 3).

${ }^{103}$ Polish Government (2000), p. 6.

${ }^{104}$ Polish Government, 'Poland's Climate Policy until 2020', Ministry of the Environment, October 2003.
} 
security. ${ }^{105}$ The 2005 address concluded that "the horizon is fortunately clear of any threats to our security". ${ }^{106}$

Although energy security was not a salient issue during this period, this did not mean that the government was completely unconcerned. For instance, Russia was framed as one of a group of "dubious suppliers", and "unfavourable prices" were considered a problem. ${ }^{107}$ Such concerns became amplified following the January 2006 supply disruption when Poland experienced a one third decrease in gas imports from Russia, when energy became clearly securitised within the country, often taking the form of 'existential threats' to national security. President Lech Kaczynski for instance alluded to Russian revanchism, stating: "I do not want to create the impression that Poland or Europe is under [military] threat, it is not [but] there are different forms of expansion. And one of them is energy". ${ }^{108}$ The Polish Foreign Minister argued that "We cannot remain defenceless nor isolated amid this increasingly threatening situation". ${ }^{109}$

\footnotetext{
${ }^{105}$ Włodzimierz Cimoszewicz (2002) Minister of Foreign Affairs Annual Address 2002, Polish Ministry of Foreign Affairs, 14 March; Cimoszewicz, Włodzimierz (2003) Minister of Foreign Affairs Annual Address 2003, Polish Ministry of Foreign Affairs, 22 January; Cimoszewicz, Włodzimierz (2004) Minister of Foreign Affairs Annual Address 2004, Polish Ministry of Foreign Affairs, 21 January.

${ }^{106}$ Adam Rotfield, 'Minister of Foreign Affairs Annual Address 2005', Ministry of Foreign Affairs, 21 January 2005, p. online.

${ }^{107}$ Polish Government, 'Energy Policy to 2025', 4 January 2005, p. 7.

${ }^{108}$ Cited in Jan Cienski and Stefan Wagstyl, 'Transcript of the FT's interview with President Lech Kaczynski', Financial Times, 6 November 2006, p. online.

${ }^{109}$ Kazimierz Marcinkiewicz, 'The European Energy Security Treaty: let us respond together to energy threats', Financial Times, 10 February 2006.
} 
Immediately after the 2006 supply disruption, the Polish Foreign Minister proposed a European Energy Security Treaty in a letter to all EU and NATO member states:

"EU member states [need a] 'firmly stated guarantee clause based on the 'musketeer principle'; '[an] expression of solidarity of its parties linking them in the face of an energy threat...[and] political decisions of suppliers." 110

The 2007 Polish National Security Strategy was similarly forthright, stating that: "[t]he dependence of Polish economy on supplies of energy resources crude oil and natural gas - from one source is the greatest external threat to our security". ${ }^{111}$ The Ministry of Economy stated that the Nord Stream gas pipeline which was being constructed between Russia to Germany (bypassing Belarus and Poland) was "a serious threat to Polish national security". ${ }^{112}$ Similar securitising moves were evident throughout 2007 and 2008, with successive Foreign Ministers frequently portraying energy dependence as a 'weapon' that was a 'threat' to national security. ${ }^{113}$

\footnotetext{
${ }^{110}$ Marcinkiewicz (2006).

111 Polish Government 'National Security Strategy 2007', 29 November 2007, p. 8, emphasis added.

112 Polish Government, 'Polish stand on the construction of the North Stream gas pipeline', Ministry of Economy, 14 May 2007b.

${ }^{113}$ Anna Fotyga, 'Minister of Foreign Affairs Annual Address 2007', Ministry of Foreign Affairs Poland 11 May 2007; Radosław Sikorski, 'Minister of Foreign Affairs Annual Address 2008', Ministry of Foreign Affairs, 2008.
} 
Such statements all indicate that energy was regarded as existentially threatened between 2006 and 2008, and even after a change in government and a 'reset' in relations with Russia, similar statements continued. Foreign policy statements constantly implied that a threat to energy security was a threat to national security and that insecurity was linked to increasing dependency and the perceived use of energy as a geopolitical tool by Russia. The Polish government prioritised energy security concerns in its foreign policy and in relations with the EU, most notably in its frequently expressed opposition to the Nord Stream pipeline, which often referenced "grand historical narratives of national identity and security". 114

The effect of the 2009 Russia-Ukraine dispute was even more serious for Poland, which lost $45 \%$ of its supplies, leaving it reliant on increased imports from Norway and its domestic gas storage. ${ }^{115}$ In reaction, the Polish Foreign Minister made a series of statements emphasising the continued risk to national security. ${ }^{116}$ In 2010 , for instance. he argued that "Poland and Europe [are] not only affected by classical threats, but also by a diverse array [of] challenges such as energy crises". ${ }^{117}$ Overall, Poland pursued an

\footnotetext{
${ }^{114}$ Stefan Bouzarovski and Marcin Konieczny, 'Landscapes of paradox: public discourses and state policies in Poland's relationship with the Nord Stream pipeline', Geopolitics 15:1 (2010), pp. 1-21: 10.

${ }^{115}$ Commission, 'Proposal for Regulation...concerning measures to safeguard security of gas supply and repealing Directive 2004/67/EC', COM(2009)363, 16 July 2009.

${ }^{116}$ Radosław Sikorski, 'Annual Address 2009', Ministry of Foreign Affairs Poland, 17 February 2009; Radosław Sikorski 'Minister of Foreign Affairs Annual Address 2010', Ministry of Foreign Affairs, 2010.

${ }^{117}$ Sikorski (2010), p. online.
} 
energy policy with the key objective of enhancing supply security through diversification (natural gas, shale gas, coal, and also nuclear), and this element of energy security has been securitised and considered an 'immediate threat' to national security. Liberalisation of energy policy was accepted to an extent, whilst maintaining a large degree of government control in energy policy, and government intervention in regulated prices (for gas) which delayed transposition of the EU's Second and Third Energy Packages.

Remarking on the Ukraine crisis in March 2014, the Prime Minister and Foreign Minister equated traditional security threats with energy security. ${ }^{118}$ The Visegrad Group, including Poland, sent a letter in March 2014 to the US Congress, stating that 'Gas-to-gas competition in our region is a vital aspect of national security'. ${ }^{119}$ Later in the year a statement on Polish Foreign Policy Goals included reference to disruptions in energy supplies as a "threat" (amongst others) facing Poland. ${ }^{120}$ Again, with the Visegrad Group, Poland sent a letter to the Commission stating that the construction

\footnotetext{
118 Donald Tusk cited in Reuters, 'Polish PM: EU should form energy union to secure supplies', 29 March 2014; Radosław Sikorski, 'Foreign Ministers of V4 Nordic and Baltic countries meet in Narva', Ministry of Foreign Affairs, 7 March 2014.

119 Josh Lederman, '4 nations urge US gas exports amid Ukraine Crisis', Washington Post, 8 March 2014.

${ }^{120}$ Polish Government, 'Minister Grzegorz Schetyna on Polish foreign policy priorities', Ministry of Foreign Affairs, 6 November 2014b.
} 
of the Nord Stream 2 may threaten the cohesion of the Common Foreign and Security Policy. ${ }^{121}$

In contrast to the riskification of gas supplies in the UK, discourses of gas insecurity have more closely conformed to a classic Copenhagen School logic of securitisation. Government claims about threats to energy being a national security issue have been consistent since January 2006, despite changes in government, and have focused overwhelmingly on the perceived vulnerability of gas supplies from Russia. This securitisation has underpinned both the government's desire for common EU action on energy security, and their hesitance to liberalise the Polish gas market in line with the European Commission's proposals.

\section{Energy governance}

As the country prepared for accession to the EU in 2004 the government sought to transpose EU market liberalisation and renewable energy production requirements into domestic law. The sector also had to deal with a transition away from domestic coal use, increasing energy demand, increasing energy imports particularly from Russia, and dramatic increases in the cost of energy to consumers and industry in the 1990s as a result of decreasing subsidies and increases in energy prices in the 2000s. Security

\footnotetext{
${ }^{121}$ Polish Government, 'Information On The Letter Of The Group Of Countries Opposing The Construction Of The Nord Stream 2 [Informacja W Sprawie Listu Grupy Państw Przeciwnych Budowie Gazociągu Nord Stream 2]', Ministry of Energy, 30 November $2015 b$.
} 
was largely subordinate to the task of transposing the main rules on internal energy markets. Liberalisation was limited as the state retained majority ownership of transmission system operators and energy companies for both electricity and gas. ${ }^{122}$

Whilst the electricity market was formally liberalised in July $2007,{ }^{123}$ there were delays in transposing the Second and Third Energy Package Directives with gas lagging behind. ${ }^{124}$ Poland was primarily concerned with how transitioning from a state-led to a market-led mode of governance may allow Russia (or 'third countries') to gain greater control of the Polish energy market. ${ }^{125}$ During the negotiation of the Third Energy Package, Poland successfully supported an option allowing the potential restriction of transmission system ownership by third-country companies on the grounds of security of supply (the 'Gazprom clause'), ${ }^{126}$ though this was weakened after pressure from Germany. ${ }^{127}$

This had a direct effect on Poland's approach to energy security in its relations with the rest of the EU. Firstly, it prioritised external energy

\footnotetext{
${ }^{122}$ Commission (2012), p. 2.

${ }^{123}$ ERO, 'National Report: The President of the Energy Regulatory Office in Poland 2015', Energy Regulatory Office, July 2015, p. 9.

${ }^{124}$ Nilsson et al. (2006), p. 2269.

${ }^{125}$ Polish Government, 'Polish position for the Energy Council of 28 February 2008 on the Third energy package', 28 February 2008.

${ }^{126}$ Directive 2009/73/EC, p. para 21.

127 Renata Goldriova, 'EU weakens 'Gazprom clause' on foreign energy investors', EU Observer, 13 October 2008.
} 
security during its Presidency in late $2011 .{ }^{128}$ Secondly, Poland continued to lag in transposition of EU rules on energy market liberalisation. ${ }^{129}$ The Russian threat was important in this process, although Nowak argues that this was underpinned by opposition from the trade unions and large incumbent energy companies, ${ }^{130}$ with policy actions defending the monopolistic status quo. ${ }^{131}$

Thirdly, Poland was a key supporter of the successful September 2011 Commission proposal for an information exchange mechanism with regard to intergovernmental agreements between Member States and third countries, ${ }^{132}$ in part to 'banish the spectre of energy-related blackmail'. ${ }^{133}$ This permitted the Commission to vet all intergovernmental agreements, and support member states at their request. ${ }^{134}$ Fourthly, Poland successfully lobbied with the UK for guidelines rather than new legislation regarding shale gas exploration. ${ }^{135}$

\footnotetext{
${ }^{128}$ Polish Government (2011).

${ }^{129}$ Commission (2012), pp. 1-2.

${ }^{130}$ Nowak (2009), p. 167.

${ }^{131}$ Aleksandra Gawlikowska-Fyk, 'How the European Union Is Shaping the Gas Market in Poland', PISM 8:56 (2013) available at: \{http://www.pism.pl/files/?id_plik=13336\} accessed 4 March 2016, p. 5.

${ }^{132}$ Krišjānis Kariṇš cited in Euractiv, 'Large countries oppose EU Gazprom deals scrutiny', Euractiv, 12 September 2012.

${ }^{133}$ Radosław Sikorski, 'Annual Address 2012', Ministry of Foreign Affairs Poland, 29 March 2012.

${ }^{134}$ European Parliament 'Better coordinated EU external energy policy', Press release Energy - 13 September 2012.

135 David Cameron, 'Letter to José Manuel Barroso', 4 December 2013; Vanessa Mock, 'EU Shies Away From Shale Gas Legislation', Wall Street Journal, 22 January 2014.
} 
In response to gas supply disruptions the 2009 Energy Strategy stated that "state intervention in the energy sector will be used exclusively to ensure security". ${ }^{136}$ In 2014 the government reiterated the role of state intervention in providing energy and national security:

"The security of the state requires...the state's influence on its implementation by energy companies, which will make it possible to respond in a fast and effective manner in the case of occurrence of threats in energy markets. It is necessary for the state to control the key infrastructure of the fuel and energy sector and to expand the supervision and control of the wealth of geological resources of the state."137

The proposal for a European Energy Security Treaty, ${ }^{138}$ invoking the necessity of legally binding solidarity, failed. However, the Lisbon Treaty included an Energy Article with a commitment for Member States to act a 'spirit of solidarity' (Article 194). In 2014 the Polish Prime Minister successfully proposed the concept of a European Energy Union, ${ }^{139}$ though its focus on security of supplies was diluted and it has evolved into a

\footnotetext{
${ }^{136}$ Polish Government, 'Energy Policy of Poland until 2030', Ministry of Economy, 2009, p. 6 .

${ }^{137}$ Polish Government, 'National Security Strategy of the Republic of Poland: 2014', 5 November 2014a, p. 55.

${ }^{138}$ Council of the European Union, 'Proposal for a European Energy Security Treaty presentation by the Polish delegation', 7160/06 2006. Brussels, p. 3.

${ }_{139}$ Donald Tusk, 'Donald Tusk on the Polish project of the European Energy Union', 29 March 2014.
} 
concept that attempts to harmonise policies on climate and energy policy, with the Polish proposal for a collective gas purchasing among member states accepted only as a possibility to be explored, and even then as voluntary, "during a crisis and where Member States are dependent on a single supplier". ${ }^{140}$

An important technical level factor in the understanding of energy security and role of the state in energy policy is the substantial shift in the geography of overall energy supply and demand, away from energy independence. Coal and lignite (brown coal) fuelled electricity generation, from domestic coal, accounted for $76 \%$ of primary energy consumption in $1990 .^{141}$ By 2013 this figure was $50 \%{ }^{142}$ Domestic production is set to decrease by 2030, with production already halving since $1990 .{ }^{143}$ Despite privatisation, the majority of mines and major companies remain state owned and the industry directly employs 100,000 and is concentrated in a particular region - Upper Silesia. ${ }^{144}$ Donald Tusk referred to coal as "the strategic

\footnotetext{
${ }^{140}$ Commission, 25 February 2015, p.6.

${ }^{141}$ OECD, 'Energy Policies of IEA Countries: Poland 2011', 2 March 2011, available at: \{http://www.oecd-ilibrary.org/energy/energy-policies-of-iea-countries-poland2011_9789264098190-en\} accessed 3 March 2016, p. 19.

${ }^{142}$ PPWB, 'Information Bulletin Lignite Producers Agreement [Biuletyn Informacyjny Porozumienia Producentów Węgla Brunatnego]', 4(89) 2014, Porozumienie Producentów Węgla Brunatnego.

${ }^{143}$ Henry Foy, 'Poland drops mine closures in the face of union threats', Financial Times, 20 January 2015.

144 ibid.
} 
foundation" of Poland's energy security. ${ }^{145}$ The country has become more dependent on the import of energy, and the Polish government has been resistant to efforts to create more ambitious environmental energy policy, and to liberalise the policy area.

In 1995 Poland was a net energy exporter, ${ }^{146}$ though since there has been growing dependence on energy imports. ${ }^{147}$ By the time of the first gas supply disruption in 2006 Poland was dependent on overall energy imports for $20 \%$ of energy consumption. This figure had increased to $32 \%$ by the second disruption in 2009 (before dropping to $29 \%$ in 2014). ${ }^{148}$ Russia supplied, through a long term contract, $75 \%$ of Polish gas in $2015 .{ }^{149}$ The decline in coal production means these gas imports constitute a growing part of the country's energy mix and significantly, the share of gas in the Polish energy mix has increased, from $4 \%$ in $2004^{150}$ to $16 \%$ in $2014^{151}$ and gas

\footnotetext{
145 Jan Cienski, 'Poland fights for coal, but Russia may benefit', Politico, 13 May 2015, available at: $\{\mathrm{http}: / / \mathrm{www}$.politico.eu/article/poland-fights-for-coal-but-russia-may-benefit/\} accessed 30 March 2016.

146 Eurostat, 'Energy dependence', tsdcc310, 28 September 2015, available at: $\{$ http://ec.europa.eu/eurostat/tgm/refreshTableAction.do?tab=table \&plugin $=1 \&$ pcode $=$ tsdc c310\&language $=$ en $\}$ accessed 1 May 2016.

${ }^{147}$ Coal imports from Russia have more than tripled in ten years, in part because of lower prices (Cienski, 2015).

${ }^{148}$ Eurostat (2015).

${ }^{149}$ ERO (2015), p. 13.

${ }^{150}$ Polish Government, 'Energy Statistics 2004, 2005', Central Statistical Office, October 2006, p. 173

${ }^{151}$ Polish Government, 'Energy 2016', Central Statistical Office, 16 June 2016, p. 8.
} 
demand is forecast to increase by over $50 \%$ by 2030 , compared with the 2009 level. $^{152}$

In the gas sector specifically, high levels of state intervention have long been apparent, with the state-owned, vertically integrated company PGNiG responsible for $89 \%$ of gas sales in $2014 .{ }^{153}$ In 2014 there was only one transmission system operator (TSO) - OGP Gaz-System S.A. - a company wholly owned by the State Treasury and supervised by the Minister of Economy until late 2015 . $^{154}$ This is explained by the strong desire to retain the state's role in guaranteeing gas supplies. ${ }^{155}$ The Polish regulator, URE, continued to set the maximum price whilst state-run distributor PGNiG sells gas to businesses and households; in response the EU Court of Justice ruled in September 2015 that Poland's regulated prices for all business consumers breached EU Internal Gas Market rules. ${ }^{156}$ In 2015, a dedicated Energy Ministry was established, concentrating the governance of energy policy previously divided between five separate ministries, and bringing state-run companies under the Ministry's control. The state retains a strong role in the Polish energy sector.

\footnotetext{
${ }^{152}$ Polish Government, 'Energy Policy of Poland until 2030', Ministry of Economy, 2009. ${ }^{153}$ ERO (2015), pp. 10-11.

${ }^{154}$ ERO (2015), p. 57.

${ }^{155}$ Adam Grzeszak cited in Jaroslaw Wisniewski, 'Towards a common understanding of energy security? An analysis of elite discourses in the UK, Poland and Germany', PhD thesis, King's College London, 2014, p. 137.

${ }^{156}$ Directive 2009/73/EC.
} 
It is argued that the change in Poland's energy mix has had a clear effect on energy policy, though it is the fact that dependence is increasing on Russia in particular that has been constructed as a threat in Poland. This dependence, particularly in the gas sector, has been used as a resource in the discursive construction of energy security in Poland. EU accession has also given the country the opportunity to develop credibility and present itself as an expert on the issue, one that is well placed to represent national but also regional and EU interests relating to both energy security and foreign policy. Despite lower overall dependence on Russian gas in the Polish energy mix, directly reliant on this source for only $10 \%$ of energy consumption, the pattern of strong reliance on Russia as a source of gas, and until recently little option to diversify supply sources, has been presented as a threat to Polish energy and also national, regional and EU security.

Whilst dependence on imports does not necessarily constitute a policy problem, as is clear in the UK case, it has been framed as problematic and threatening in the case of Poland. Part of the explanation is related to historical relations with Russia and concerns regarding Ukraine dating back at least a decade, when Poland positioned itself as a leader on the EU's Eastern Partnership strategy that included Ukraine. However, the 'securitisation' of energy in Poland is not merely a discursive phenomenon. Whilst Poland has long been almost completely dependent on imports of gas from Russia this constituted a relatively small share of energy consumption 
in the 1990s. Since the turn of the century there has been a significant material increase in Russian gas imports as domestic coal production decreases. Securitisation thus occurred, enabled by state-led mode of energy governance in Poland, where the Polish state has played a central role in directing and implementing energy policy to achieve energy and political objectives.

\section{Conclusion}

This article has demonstrated that going beyond the Copenhagen School conceptualisation of securitisation has considerable potential for examining the construction of energy security issues and the potential for further energy policy integration in the EU. Combining elements of both the philosophical and sociological wings of securitisation studies we have sought to address two research questions. First, has gas been constructed as a security issue and, if so, what form do those constructions take? Second, have technical and economic factors played a role in shaping these attempts to construct gas as a security issue?

We have demonstrated that for the governments of both countries, energy security has become a policy priority and gas supplies have been constructed in terms of security. However, understandings of the extent, sources and form of insecurity have differed substantially. In the case of Poland, these constructions have most closely followed a classic 
Copenhagen School logic of securitisation. Successive governments have repeatedly linked gas supplies with national security, making claims about the existential threat posed by its main supplier, Russia, potentially using energy as 'a weapon' to exploit Polish dependence on gas imports. In the case of the UK, by contrast, a logic of riskification is more evident. Government claims have centred on the UK's potential vulnerability to risks emerging from its greater exposure to the European and international gas markets.

Contextual conditions have played an important role in this process in both cases. The UK and Poland have significantly different state-market relations which has shaped the form that constructions of gas as a security issue have taken, leading to riskification in the former and securitisation in the latter. Prior to 2006, the UK adopted a completely market-led approach to the governance of gas, enabled by its 'energy independence'. Investment decisions taken by the private sector in anticipation of the UK becoming import dependent altered the dynamics of the market, resulting in the government identifying risks that resulted in it developing a limited role in providing strategic direction to market participants to build the resilience of the market. This involved a greater level of governmental influence rather than a radical reassertion of state control.

In Poland the government asserted its role in ensuring the security of gas supplies through control of the monopoly gas transmissions systems 
operator, and the dominant gas importer and seller. This was justified on the grounds of a shift from 'energy independence' to an increasing dependence on gas imports from a single supplier: Russia. The government has played a leading role in attempting to diversify supplies and both developing and strengthening interconnections with neighbouring gas markets.

These twin findings have broader implications for debates about the potential for the development of a common EU energy policy. The Commission's efforts to develop a market-led system of energy governance across the Member States could, if successful, permit a degree of consensus around the form of security construction. However, if we accept that gas supplies have been constructed as security issues in different forms in the UK and Poland, that these states are exemplars of different modes of energy governance among the EU Member States, and that such modes of energy governance are to an extent predisposed to different forms of security construction, ${ }^{157}$ then there are significant challenges to reconciling these different forms of security construction and energy governance.

This poses major challenges for further integration because even if there is intersubjective agreement within the EU that gas supplies are a security

\footnotetext{
${ }^{157}$ Further research is required to examine this claim in other Member States, and in particular to examine how the dynamics of securitisation and riskification may play out in systems that do not align so clearly with the state-led/market-led distinction we have utilised in this article. This could also explore aspects of the process of constructing energy security that we have not been able to examine in this article, such as the role of practices in contributing to the process of securitisation/riskification.
} 
issue, if the Member States cannot agree on what kind of security issue gas supplies represent then the development of a common approach for dealing with these threats and/or risks would appear unlikely. For proponents of further integration this is concerning, since claims about gas insecurity have long been central to the Commission's attempts to develop a common EU energy policy. While the Commission has continued to argue in response to the crisis in Ukraine that, "more coordination of national energy policies is necessary to respond credibly to the challenge of energy security", ${ }^{158}$ there are clear limits to the ability of 'security' to mobilise support in favour of further integration.

${ }^{158}$ Commission (2014), p. online. 


\section{Ethical Statement}

This research adheres to the ethical standards, legal requirements of the study countries. There is no conflict of interest, and no financial support to declare. 